\title{
Arsitektur Berkelanjutan pada Sekolah Tinggi Astronomi DAN KEDIRGANTARAAN DI YOGYAKARTA
}

\author{
Tiara Arini, Agung Kumoro Wahyuwibowo, Tri Yuni Iswati \\ Program Studi Arsitektur \\ Universitas Sebelas Maret \\ Email: arini.tiara@student.uns.ac.id
}

\begin{abstract}
Astronomy is a natural science that studies celestial objects and phenomena that include observation and explanation, occurs outside Earth and its atmosphere. Location of Indonesia which is at the equator enables the constellations in north sky and south sky can be observed very well. In Asia Pacific, astronomy in Indonesia is also growing and interested by many researchers from abroad. Astronomy also has relationship with aerospace engineering. Aerospace engineering studies about aircraft design. PT Dirgantara Indonesia is also the first and only one aircraft company in Southeast Asia. However, there are obstacles in these potentials, as in Indonesia, astronomy formal education is only at Institut Teknologi Bandung (ITB). Besides, facilities and infrastructures to study astronomy are still concentrated in Java. Yogyakarta is known as "Kota Pelajar" where the dynamics of education and tourism are strong enough to make it possible to deliver a High School of Astronomy and Aerospace, precisely in Gunungkidul Regency. Gunungkidul have ecological conditions that are still green and far away from the word "metropolitan" so as can be a place to facilitate astronomical observation. From this location, Sustainable Architecture becomes an approach that combines the aspects of efficiency, conservation, and durability that can be applied to the building and the environment. The efficiency is applied in energy use, particularly in the use of sun light and wind direction, as well as the efficiency of land use, so that not all of the site is covered by buildings that can provide green open space. On the conservation aspect is closely linked to sustainable development, especially in the use of natural resources. Conservation will keep the natural resources remain on a sustainable point. Durability is the resistance of a building and environment. In this case, how to make the building can last a long time because of the threat around the environment is minimized. It begins from site planning, the use of land that is not harmful to the building and surrounding communities.
\end{abstract}

Keywords: aerospace, astronomy, education, Gunungkidul, high school, sustainable architecture.

\subsection{PENDAHULUAN}

Astronomi merupakan salah satu cabang ilmu pengetahuan yang mempelajari objek ruang angkasa (bintang, planet, komet, nebula, gugus bintang, atau galaksi) dan fenomena-fenomena yang melibatkan pengamatan dan penjelasan kejadian yang terjadi di luar bumi dan atmosfer. Indonesia yang berada di garis khatulistiwa memiliki begitu banyak potensi untuk meningkatkan kualitas dalam Bidang Astronomi. Letak Indonesia yang berada di ekuator juga memungkinkan gugusan bintang di langit Utara dan Selatan dapat terobservasi.
Mantan Kepala Lembaga Penerbangan dan Antariksa Nasional (LAPAN), Bambang Tedjakusuma, mengklaim bahwa astronomi di Indonesia paling maju se-Asia Tenggara. Menurut beliau, observasi dan ahli astronomi di Indonesia kian meningkat. Selain itu, banyak pula warga dan penggiat astronomi amatir yang tertarik dengan fenomena-fenomena alam di ruang angkasa. Terlebih dengan didukung UU Keantariksaan Nomor 21 tahun 2013 yang menjadi payung hukum yang setidaknya semakin meningkatkan perkembangan astronomi dan keantariksaan di Indonesia. Di Asia Pasifik, 
astronomi Indonesia juga semakin berkembang dan diminati banyak peneliti dari luar negeri.

Satu hal yang cukup berseberangan dengan kondisi astronomi di Indonesia, yaitu keberadaan jurusan astronomi yang hanya ada di Institut Teknologi Bandung (ITB). Bahkan hanya di Asia Tenggara. Inilah yang membuat Indonesia mengalami krisis pendidikan formal astronomi.

Astronomi juga memiliki hubungan dengan pendidikan teknik kedirgantaraan (aerospace engineering). Teknik kedirgantaraan yang akan merancang mesin-mesin pesawat terbang. Perusahaan pesawat terbang PT Dirgantara Indonesia juga merupakan perusahaan pesawat terbang pertama dan hanya satu di Asia Tenggara. Cukup banyak potensi yang dimiliki Indonesia pada bidang astronomi, aeronautika, dan astronautika. Menurut Hakim Luthfi Malasa, seorang ahli astronomi dari ITB, sarana dan prasarana untuk mempelajari astronomi masih terpusat di Pulau Jawa sehingga belum memungkinkan untuk mengadakan pembelajaran astronomi selain di Pulau Jawa karena permasalahan utama adalah pada sumber daya manusia (SDM).

Yogyakarta sebagai Kota Pelajar memiliki dinamika bidang pendidikan dan pariwisata yang cukup kuat. Di Yogyakarta juga terdapat sebuah komunitas astronom amatir yang bernama Jogja Astro Club (JAC) dan Bandara Internasional Adi Sutjipto di Sleman serta lapangan terbang TNI AU di Gunungkidul yang dapat menunjang kegiatan di Sekolah Tinggi Astronomi dan Kedirgantaraan.

Di Yogyakarta, daerah yang paling memungkinkan untuk dilakukan pengamatan astronomi adalah Kabupaten Gunungkidul. Lokasi tersebut jauh dari Gunung Merapi dan masih memiliki kondisi ekologi yang hijau. Lokasi Gunung Merapi dihindari karena akan ada bagian langit yang tertutup gunung saat observasi dan status Gunung Merapi masih menjadi gunung api aktif. Yogyakarta juga masih memiliki kultur yang kental sehingga masyarakat masih menjaga kondisi fisik ekologi tempat tinggal. Hal-hal inilah yang menjadi potensi untuk menghadirkan sebuah Sekolah Tinggi Astronomi dan Kedirgantaraan di Kabupaten Gunungkidul.
Arsitektur keberlanjutan sangat memperhatikan kondisi lingkungan sekitar agar sumber daya alam dapat bertahan lebih lama. Secara umum, arsitektur berkelanjutan membawa tiga misi, yaitu efisiensi, konservasi, dan durabilitas yang diterapkan pada bangunan serta lingkungan. Agar lingkungan yang masih hijau tetap terjaga, maka arsitektur berkelanjutan dirasa tepat sebagai sebuah pendekatan dalam perancangan Sekolah Tinggi Astronomi dan Kedirgantaraan.

\subsection{METODE}

Metode yang digunakan pada perancangan Sekolah Tinggi Astronomi dan Kedirgantaraan adalah penerapan arsitektur berkelanjutan. Arsitektur berkelanjutan adalah arsitektur yang memenuhi kebutuhan saat ini, tanpa membahayakan kemampuan generasi mendatang, dalam memenuhi kebutuhan mereka sendiri. Kebutuhan itu berbeda dari satu masyarakat ke masyarakat lain, dari satu kawasan ke kawasan lain dan paling baik bila ditentukan oleh masyarakat terkait (Steele, 1997). Bangunan berkelanjutan mungkin disebut sebagai bangunan "hijau," "kinerja tinggi," atau "efisiensi energi," tetapi masing-masing dari istilah merujuk pada bangunan yang memperkecil penggunaan energi, air, dan sumber daya alam yang lain serta menyediakan lingkungan dalam ruang yang sehat dan produktif. Dalam keberlanjutan, ada tiga faktor penting yang tergabung di dalamnya, yaitu masyarakat, ekonomi, dan lingkungan (Neuman, 2003). Elemen masyarakat, ekonomi, dan lingkungan secara makro merupakan prinsip utama dari pembangunan berkelanjutan.

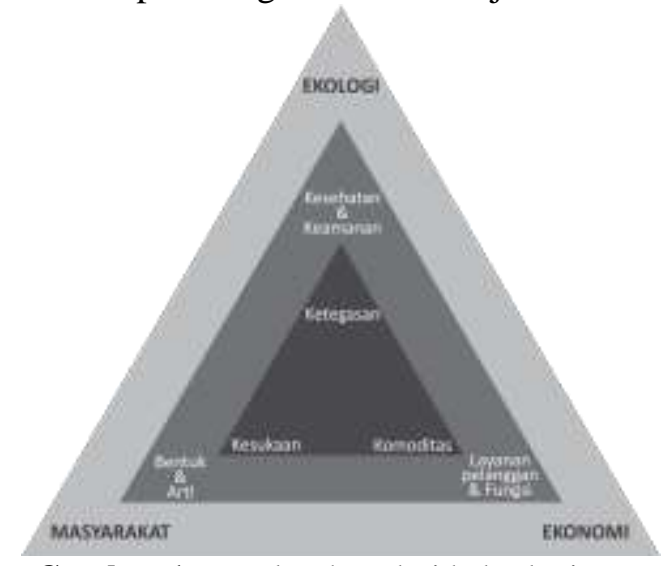

Gambar 1. Keseluruhan dari keberlanjutan. 
Dari pengertian tentang arsitektur berkelanjutan tersebut, penulis merangkum tiga aspek yang akan diaplikasikan dalam Sekolah Tinggi Astronomi dan Kedirgantaraan. Aspek tersebut adalah sebagai berikut.

1. Efisiensi

Efisiensi merupakan efisiensi dalam penggunaan energi, terutama dalam pemanfaatan sinar matahari sebagai pencahayaan alami, arah angin sebagai penghawaan, dan pemanfaatan bukaan sebagai cross ventilation. Selain efisiensi dalam penggunaan energi, efisiensi penggunaan lahan, yaitu tidak semua lahan harus ditutup dengan bangunan sehingga dapat menyediakan lahan terbuka hijau.

2. Konservasi

Konservasi berhubungan erat dengan pembangunan berkelanjutan, terutama pada pemanfaatan sumber daya alam. Konservasi yang menjaga SDA tetap berada pada titik berkelanjutan, misal pada penggunaan material kayu. Kayu yang digunakan adalah kayu dari pohon jati yang sudah tua dan berada di sekitar lingkungan. Sebelum pohon jati tersebut ditebang, sudah ditanami pohon jati muda sehingga keberadaan pohon jati di sekitar lingkungan tidak musnah.

3. Durabilitas

Durabilitas merupakan ketahanan dari sebuah bangunan atau lingkungan perancangan. Maka, bagaimana membuat bangunan bisa bertahan lama karena ancaman di sekitar lingkungan yang diminimalisasi. Diawali dari perencanaan tapak, yaitu menggunakan lahan yang tidak membahayakan bagi bangunan dan masyarakat sekitar. Contohnya dengan tidak membangun bangunan di daerah yang rawan longsor, maka telah membantu lingkungan sekitar mengurangi bahaya longsor dari tanah yang tidak mampu menahan beban bangunan.

\subsection{ANALISIS}

\subsection{Analisis Peruangan}

Kebutuhan ruang yang muncul merupakan pertimbangan dari pelaku dan kegiatan di Sekolah Tinggi Astronomi dan Kedirgantaraan.
Tabel 1. Kebutuhan Ruang pada Sekolah Tinggi Astronomi dan Kedirgantaraan

\begin{tabular}{|c|c|c|}
\hline Pelaku & Kegiatan & Ruang \\
\hline \multirow{16}{*}{$\begin{array}{l}\text { Maha- } \\
\text { siswa }\end{array}$} & Parkir & Lahan parkir \\
\hline & $\begin{array}{l}\text { Menghadiri } \\
\text { kegiatan } \\
\text { perkuliahan }\end{array}$ & Ruang-ruang kelas \\
\hline & $\begin{array}{l}\text { Praktik } \\
\text { perkuliahan }\end{array}$ & $\begin{array}{l}\text { Laboratorium/ } \\
\text { observatorium }\end{array}$ \\
\hline & $\begin{array}{l}\text { Konsultasi dan } \\
\text { asistensi }\end{array}$ & $\begin{array}{l}\text { R. Konsultasi/R. } \\
\text { Dosen }\end{array}$ \\
\hline & $\begin{array}{ll}\text { Diskusi } & \text { dan } \\
\text { membaca } & \\
\end{array}$ & Perpustakaan \\
\hline & $\begin{array}{l}\text { Mengerjakan } \\
\text { tugas }\end{array}$ & $\begin{array}{l}\text { Komunal, } \\
\text { perpustakaan }\end{array}$ \\
\hline & $\begin{array}{l}\text { Seminar, kuliah } \\
\text { umum, atau } \\
\text { presentasi }\end{array}$ & $\begin{array}{l}\text { Auditorium, ruang } \\
\text { seminar }\end{array}$ \\
\hline & Olahraga & Lapangan \\
\hline & $\begin{array}{l}\text { Mengikuti } \\
\text { agenda prodi }\end{array}$ & R. Rapat Prodi \\
\hline & $\begin{array}{l}\text { Mengikuti } \\
\text { ekstrakurikuler }\end{array}$ & $\begin{array}{l}\text { Ruang-ruang } \\
\text { UKM }\end{array}$ \\
\hline & Akses internet & $\begin{array}{l}\text { Komunal, } \\
\text { perpustakaan, } \\
\text { ruang kelas }\end{array}$ \\
\hline & $\begin{array}{l}\text { Kegiatan } \\
\text { keasramaan }\end{array}$ & Asrama \\
\hline & $\begin{array}{l}\text { Mengobrol, } \\
\text { bersantai }\end{array}$ & Komunal \\
\hline & Ibadah sholat & Masjid \\
\hline & $\begin{array}{l}\text { Makan dan } \\
\text { minum }\end{array}$ & Kantin \\
\hline & Metabolisme & KM/WC \\
\hline \multirow{4}{*}{ Dosen } & Parkir & Lahan parkir \\
\hline & Absensi & R. absensi \\
\hline & $\begin{array}{l}\text { Menyiapkan } \\
\text { materi } \\
\text { perkuliahan } \\
\end{array}$ & R. dosen \\
\hline & Memberikan & Ruang-ruang kelas \\
\hline
\end{tabular}




\begin{tabular}{|c|c|c|c|c|}
\hline & $\begin{array}{l}\text { materi } \\
\text { perkuliahan }\end{array}$ & & $\begin{array}{l}\text { kegiatan } \\
\text { akademik }\end{array}$ & akademik \\
\hline & teori & & Memimpin dan & R. Kaprodi \& \\
\hline & $\begin{array}{l}\text { Memberikan } \\
\text { materi }\end{array}$ & Laboratorium & $\begin{array}{l}\text { mengawasi } \\
\text { prodi }\end{array}$ & Sekprodi \\
\hline & $\begin{array}{l}\text { perkuliahan } \\
\text { praktik }\end{array}$ & & $\begin{array}{l}\text { Mengurus } \\
\text { kegiatan }\end{array}$ & R. Ketua LPPM \\
\hline & $\begin{array}{l}\text { Memberikan } \\
\text { konsultasi atau } \\
\text { asistensi }\end{array}$ & $\begin{array}{l}\text { R. konsultasi/ R. } \\
\text { dosen }\end{array}$ & $\begin{array}{l}\text { penelitian dan } \\
\text { pengabdian } \\
\text { masyarakat }\end{array}$ & \\
\hline & $\begin{array}{l}\text { Mengawasi } \\
\text { kegiatan } \\
\text { praktik } \\
\text { perkuliahan } \\
\end{array}$ & Laboratorium & $\begin{array}{l}\text { Mengurus } \\
\text { kegiatan } \\
\text { penelitian } \\
\text { LPPM } \\
\end{array}$ & $\begin{array}{l}\text { R. Sekbid \& staff } \\
\text { Penelitian }\end{array}$ \\
\hline & $\begin{array}{l}\text { Menghadiri } \\
\text { rapat prodi }\end{array}$ & R. rapat & $\begin{array}{l}\text { Mengurus } \\
\text { kegiatan }\end{array}$ & $\begin{array}{l}\text { R. Sekbid \& staff } \\
\text { Pengmas }\end{array}$ \\
\hline & $\begin{array}{l}\text { Melakukan } \\
\text { administrasi } \\
\text { pengajaran }\end{array}$ & R. pengajaran & $\begin{array}{l}\text { pengabdian } \\
\text { masyarakat } \\
\text { LPPM }\end{array}$ & \\
\hline & $\begin{array}{l}\text { Melakukan } \\
\text { koordinasi } \\
\text { dengan dosen } \\
\text { lain } \\
\end{array}$ & R. dosen & $\begin{array}{l}\text { Mengurus } \\
\text { administrasi, } \\
\text { dokumen, dan } \\
\text { keuangan }\end{array}$ & $\begin{array}{l}\text { R. Bagian TU dan } \\
\text { Keuangan }\end{array}$ \\
\hline & $\begin{array}{l}\text { Menemui } \\
\text { dosen tamu }\end{array}$ & R. tamu & $\begin{array}{l}\text { Mengurus } \\
\text { kegiatan diklat }\end{array}$ & $\begin{array}{l}\text { R. bag. } \\
\text { Kemahasiswaan }\end{array}$ \\
\hline & $\begin{array}{l}\text { Mendampingi } \\
\text { kegiatan } \\
\text { kemahasiswaan }\end{array}$ & Ruang UKM & $\begin{array}{l}\text { dan kerja sama; } \\
\text { kemahasiswaan } \\
; \quad \text { dan }\end{array}$ & \\
\hline & Mengadakan & Auditorium, ruang & kealumnian & \\
\hline & & seminar & $\begin{array}{l}\text { Mengurus } \\
\text { laboratorium }\end{array}$ & $\begin{array}{l}\text { R. UPT } \\
\text { Laboratorium }\end{array}$ \\
\hline & seminar & & Mengurus & R. UPT \\
\hline & Menyimpan & Loker & perpustakaan & Perpustakaan \\
\hline & barang pribadi, & & Ibadah sholat & Masjid \\
\hline & menerima surat & & Makan dan & Pantry, dapur \\
\hline & Menyimpan & R. penyimpanan & minum & \\
\hline & alat dan bahan & & Metabolisme & KM/WC \\
\hline & perkuliahan & & Menyimpan & R. janitory \\
\hline & Ibadah sholat & Masjid & alat-alat & \\
\hline & Makan dan & Pantry, dapur & kebersihan & \\
\hline & minum & & Mengawasi & R. Pustakawan \\
\hline & Metabolisme & KM/WC & kegiatan & \\
\hline & Parkir & Lahan parkir & perpustakaan & \\
\hline & & & Memasak & Dapur \\
\hline & Absensi & R. absensi & Menjaga & Pos satpam \\
\hline Penge- & Memimpin dan & R. Rektor dan & keamanan & \\
\hline lola & $\begin{array}{l}\text { mengawasi } \\
\text { kampus }\end{array}$ & Wakil Rektor & Aktivitas & $\begin{array}{l}\text { Kebutuhan } \\
\text { Ruang }\end{array}$ \\
\hline & Menerima tamu & R. tamu & & \\
\hline & Rapat & R. Rapat Rektorat & Perawatan & Medical center \\
\hline & Mengurus & R. bagian & kesehatan & \\
\hline
\end{tabular}




\begin{tabular}{|c|c|c|}
\hline & $\begin{array}{l}\text { Menaruh/meng } \\
\text { ambil barang }\end{array}$ & Loker \\
\hline & Ibadah sholat & Masjid \\
\hline & $\begin{array}{l}\text { Makan dan } \\
\text { minum }\end{array}$ & Dapur, kantin \\
\hline & Metabolisme & KM/WC \\
\hline \multirow{11}{*}{$\begin{array}{l}\text { Pengun- } \\
\text { jung }\end{array}$} & Parkir & Lahan parkir \\
\hline & $\begin{array}{l}\text { Mengecek } \\
\text { kinerja kampus }\end{array}$ & R. tamu \\
\hline & $\begin{array}{l}\text { Mencari } \\
\text { literatur }\end{array}$ & Perpustakaan \\
\hline & $\begin{array}{l}\text { Menghadiri } \\
\text { seminar }\end{array}$ & $\begin{array}{l}\text { Auditorium, R. } \\
\text { Seminar }\end{array}$ \\
\hline & $\begin{array}{l}\text { Menghadiri } \\
\text { acara } \\
\text { kemahasiswaan }\end{array}$ & $\begin{array}{l}\text { R. UKM atau } \\
\text { menyesuaikan }\end{array}$ \\
\hline & $\begin{array}{l}\text { Meninjau } \\
\text { kinerja kampus } \\
\text { Mengaudit } \\
\text { system } \\
\text { akademik } \\
\text { Kunjungan } \\
\text { akademis } \\
\text { Menghadiri } \\
\text { undangan } \\
\end{array}$ & $\begin{array}{l}\text { R. tamu atau } \\
\text { menyesuaikan }\end{array}$ \\
\hline & $\begin{array}{l}\text { Mengadakan } \\
\text { atau } \\
\text { menghadiri } \\
\text { seminar }\end{array}$ & $\begin{array}{l}\text { Auditorium, R. } \\
\text { seminar }\end{array}$ \\
\hline & $\begin{array}{l}\text { Menghadiri } \\
\text { undangan }\end{array}$ & $\begin{array}{l}\text { R. tamu atau } \\
\text { menyesuaikan }\end{array}$ \\
\hline & $\begin{array}{l}\text { Menghadiri } \\
\text { seminar } \\
\text { Mengadakan } \\
\text { kuliah umum } \\
\text { Mengadakan } \\
\text { diskusi }\end{array}$ & $\begin{array}{l}\text { Auditorium, R. } \\
\text { Seminar, atau } \\
\text { menyesuaikan }\end{array}$ \\
\hline & $\begin{array}{l}\text { Menghadiri } \\
\text { seminar }\end{array}$ & $\begin{array}{l}\text { Auditorium, R. } \\
\text { Seminar, atau } \\
\text { menyesuaikan }\end{array}$ \\
\hline & $\begin{array}{l}\text { Mengunjungi } \\
\text { pertunjukan di } \\
\text { kampus }\end{array}$ & $\begin{array}{l}\text { Menyesuaikan } \\
\text { pertunjukan }\end{array}$ \\
\hline
\end{tabular}

\subsection{Analisis Pemilihan Tapak}

Lokasi perancangan terletak di Desa Gading, Kec. Playen, Kab. Gunungkidul. Di desa tersebut terdapat lapangan udara milik TNI AU yang juga biasa digunakan oleh taruna/i dari sekolah penerbangan milik Yayasan TNI AU di Yogyakarta.

Setelah didapatkan lokasi, kemudian mencari tapak dengan pertimbangan sebagai berikut.

- Mudah dijangkau dan dilewati jalan arteri.

- Memiliki persyaratan terhadap RTRW.

- Masih terdapat lahan kosong tanpa bangunan.

- Terdapat sarana dan infrastruktur yang menunjang kegiatan belajar.

Dari pertimbangan tersebut didapatkan dua alternatif lokasi.

1. Alternatif 1

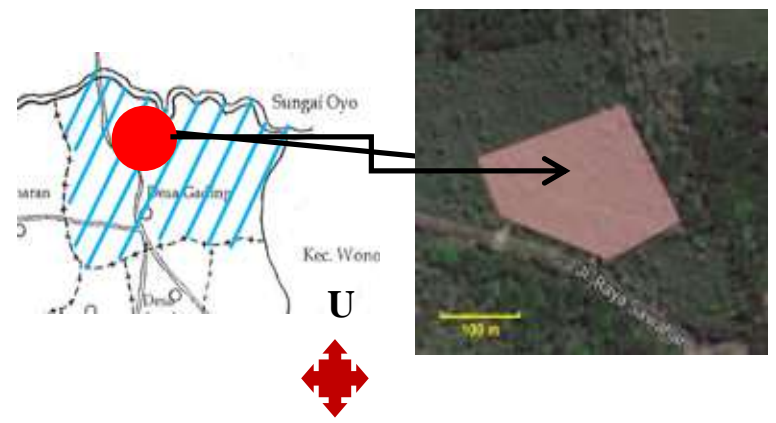

- Terletak di Desa Gading sebelah barat laut.

- Dilewati oleh jalan utama, yaitu Jl. Nasional III (atau Jl. Raya Sawahan).

- Luas site \pm 3 Ha. Jauh dari permukiman penduduk.

- Jarak dari lokasi site ke Lanud Gading yang nantinya digunakan sebagai tempat praktik penerbangan adalah $\pm 2,2 \mathrm{~km}$.

\section{Alternatif 2}

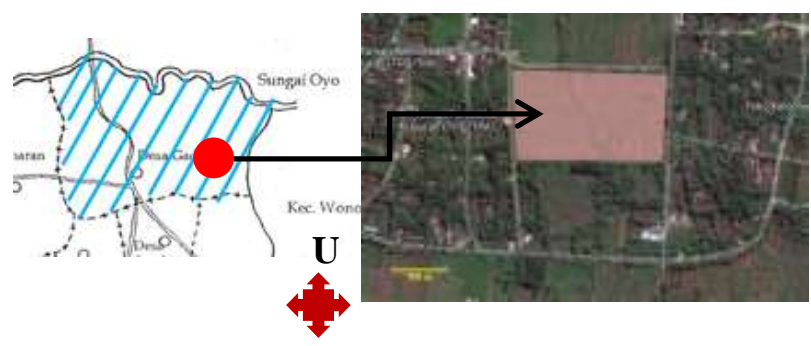

- Terletak di Desa Gading sebelah tenggara.

- Luas site \pm 3 Ha.

- Dekat dengan permukiman penduduk.

- Jarak dari lokasi site ke Lanud Gading yang nantinya digunakan sebagai tempat praktik penerbangan adalah $\pm 700 \mathrm{~m}$.

Dari dua alternatif di atas, dipilih alternatif 1 sebagai lokasi tapak perancangan. 


\subsection{Analisis Pencapaian}

Pencapaian ke dalam objek harus mudah dilihat dan diakses dari jalan utama.

\subsubsection{Tujuan}

Menentukan ME, SE, dan jalur exit.

\subsubsection{Dasar pertimbangan}

Pencapaian yang mudah diakses dari jalan utama, arus kendaraan dari jalan utama, menghindari crossing.

\subsubsection{Proses analisis}

ME dan exit merupakan gerbang utama untuk masuk dan keluar dari lokasi. ME digunakan untuk akses oleh semua pelaku kegiatan. SE digunakan untuk akses cepat menuju ke zona pendidikan.

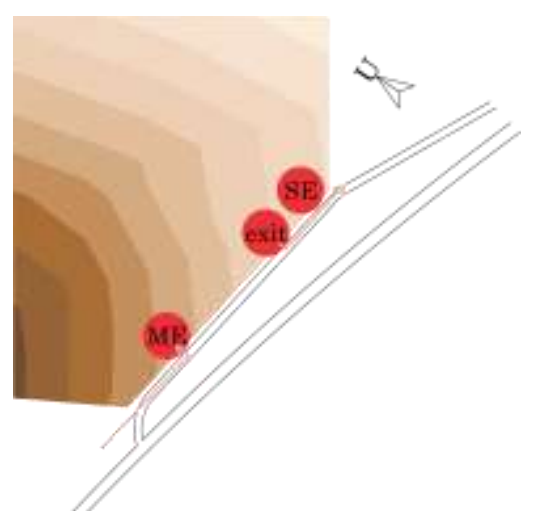

Gambar 2. Pola pencapaian pada tapak.

\subsection{Analisis View dan Orientasi}

\begin{tabular}{llr}
\multicolumn{1}{c}{ Sekolah Tinggi Astronomi } & dan \\
Kedirgantaraan merupakan sebuah & objek \\
pendidikan yang tidak memerlukan & view \\
maksimal.
\end{tabular}

\subsubsection{Tujuan}

Menentukan view dan orientasi kawasan.

\subsubsection{Dasar pertimbangan}

Pencapaian dan kondisi di sekitar tapak yang berupa daerah hijau dan banyak terdapat hutan. Di sebelah timur tapak terdapat Tahura Bunder yang merupakan tempat wisata. Di sebelah utara terdapat Sungai Oyo.

\subsubsection{Proses analisis}

Membuat pola orientasi yang mudah dikenali dari jalan utama.

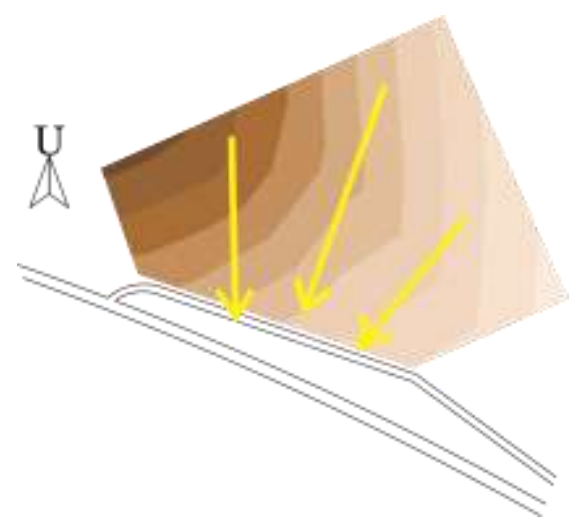

Gambar 3. View dan orientasi bangunan menghadap ke jalan utama.

\subsection{Analisis Penyinaran Matahari}

Penyinaran matahari dapat berguna sebagai penyinaran alami.

\subsubsection{Tujuan}

Menentukan barrier pada bangunan.

\subsubsection{Dasar pertimbangan}

Posisi pergerakan matahari. Sinar matahari pagi baik untuk kesehatan, sedangkan pada siang hari dapat menyebabkan penyakit bila terpapar secara langsung.

\subsubsection{Proses analisis}

Melihat pergerakan matahari pada kawasan bangunan.

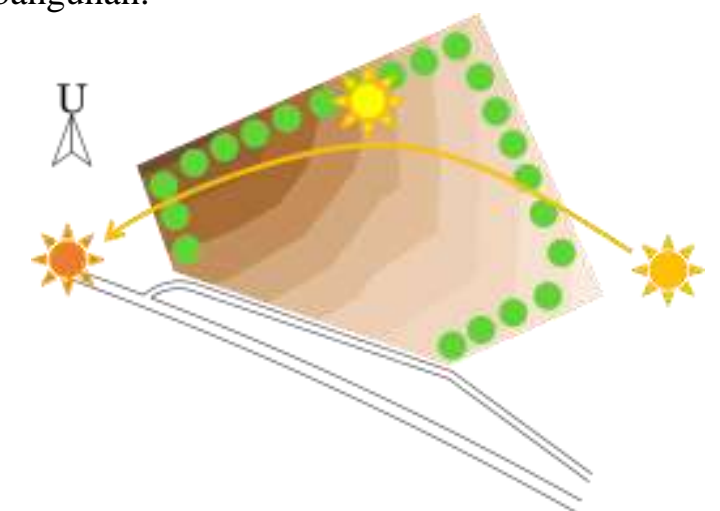

Gambar 4. Pergerakan matahari pada kawasan.

Salah satu potensi pada site adalah site berupa daerah hijau yang masih cenderung sebagai hutan yang ditanami sebagian besar pohon jati. Di sebelah timur dan barat site merupakan kawasan hutan yang bisa menjadi barrier alami.

\subsection{Analisis Pergerakan Angin}

Pergerakan angin berguna untuk memberikan penghawaan alami pada bangunan.

\subsubsection{Tujuan}


Menentukan arah bukaan pada bangunan.

\subsubsection{Dasar pertimbangan}

Menurut data di BPS Daerah Istimewa Yogyakarta, arah angin adalah menuju Barat Daya pada keadaan tekanan minimum dan menuju selatan pada keadaan tekanan maksimum

\subsubsection{Proses analisis}

Membuat pola pergerakan angin pada tapak.

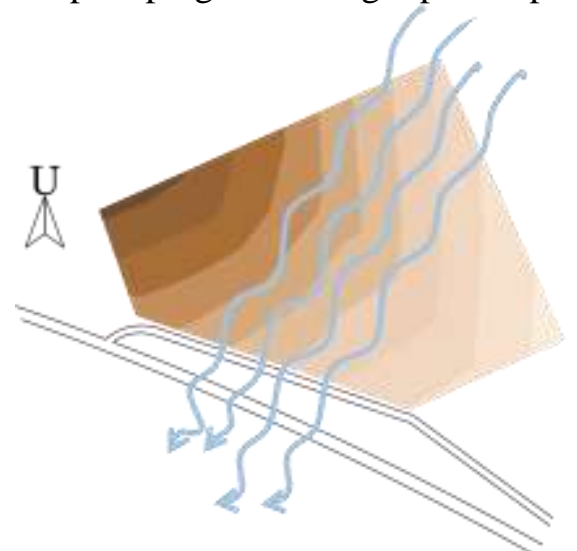

Gambar 5. Arah pergerakan angin pada tapak.

\subsection{Analisis Pemintakatan}

Pemintakatan dilakukan berdasarkan sifat kegiatan, kebutuhan ruang, dan kedekatan pola ruang.

\subsubsection{Tujuan}

Menentukan mintakatan yang sesuai dengan pola hubungan ruang.

\subsubsection{Dasar pertimbangan}

Analisis peruangan dan tapak serta pola hubungan ruang makro.

\subsubsection{Proses analisis}

Membuat pola hubungan makro yang kemudian dituangkan ke tapak.

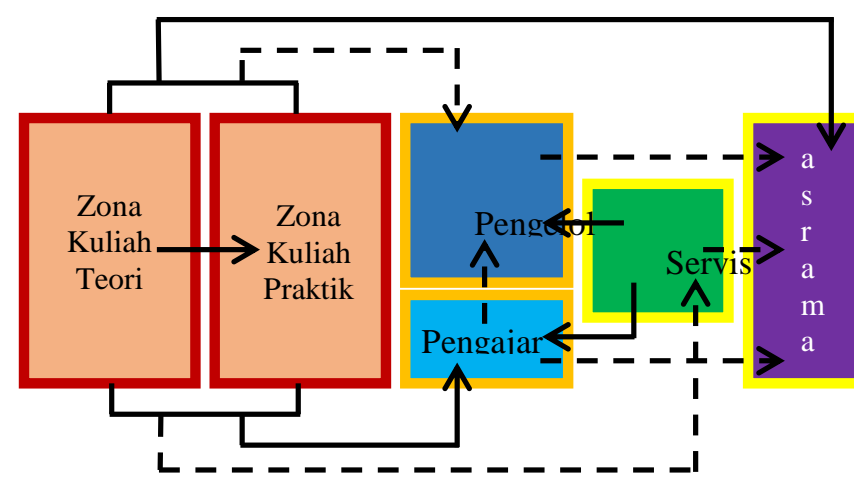

Skema 1. Hubungan makro kawasan bangunan.

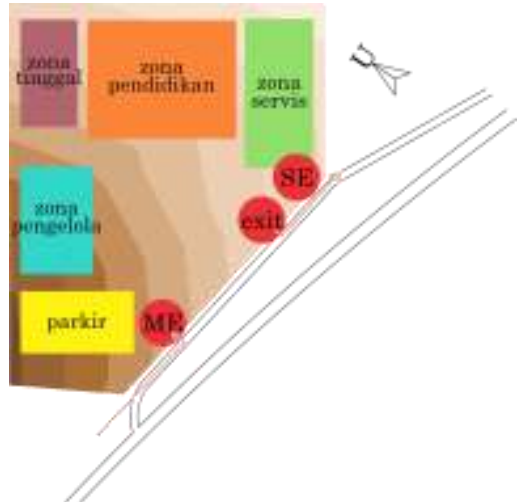

Gambar 6. Pemintakatan akhir pada tapak.

\subsection{Analisis Sirkulasi} pelaku.

Sirkulasi harus dapat mengarahkan

\subsubsection{Tujuan}

Menentukan alur sirkulasi pada kawasan tapak.

\subsubsection{Dasar pertimbangan}

Analisis pemintakatan dan analisis tapak.

\subsubsection{Proses analisis}

Menentukan sirkulasi kegiatan untuk masingmasing kelompok pelaku kegiatan.

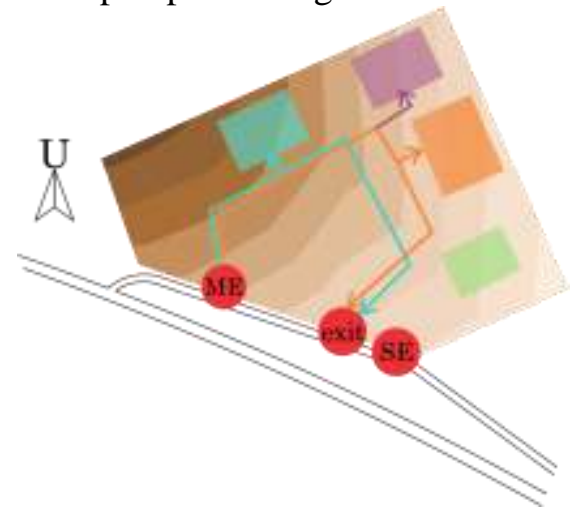

Gambar 7. Sirkulasi pada tapak.

\subsection{Analisis Massa}

Sekolah Tinggi Astronomi dan Kedirgantaraan bukanlah bangunan yang terdiri hanya dari satu massa, tetapi merupakan kesatuan dari beberapa massa. Tiap zona ruang merupakan massa tersendiri karena fungsi dari ruangnya pun sudah berbeda.

Dalam menentukan massa bangunan, hal yang perlu diperhatikan adalah sebagai berikut.

1. Fleksibilitas ruang.

2. Keselarasan dengan kondisi tapak dan iklim.

3. Kedekatan ruang sejenis. 
Tabel 2. Bentuk massa dan karakteristiknya.

\begin{tabular}{|l|l|}
\hline Bentuk Massa & \multicolumn{1}{|c|}{ Karakteristik } \\
\hline & $\begin{array}{l}\text { Bentuk dasar persegi } \\
\text { cenderung memiliki kesan } \\
\text { formal. } \\
\text { - Pemanfaatan ruang dapat } \\
\text { lebih optimal karena sudut } \\
\text { yang dibentuk. }\end{array}$ \\
\hline & $\begin{array}{l}\text { Bentuk dasar lingkaran } \\
\text { cenderung memiliki sifat } \\
\text { yang kurang formal. } \\
\text { - Pemanfaatan ruang tidak } \\
\text { begitu optimal tetapi } \\
\text { menghasilkan bentuk yang } \\
\text { organis. }\end{array}$ \\
\hline
\end{tabular}

\subsection{Analisis Warna}

Warna merupakan unsur yang dapat menggambarkan suasana. Selain itu, warna juga dapat memberikan efek psikologis sendiri terhadap pelaku dari bangunan.

Tabel 3. Warna dan kesan warna.

\begin{tabular}{|c|l|}
\hline \multicolumn{1}{|c|}{ Warna } & \multicolumn{1}{|c|}{ Kesan Warna } \\
\hline $\begin{array}{c}\text { Krem atau putih } \\
\text { Shocking pink } \\
\text { sholet atau }\end{array}$ & Lembut, elegan \\
\hline Biru & $\begin{array}{l}\text { Dingin, } \\
\text { modern }\end{array}$ \\
\hline Hijau-biru & Menyegarkan, bersih \\
\hline Hijau & Menenangkan \\
\hline Kuning-jingga & $\begin{array}{l}\text { Manis harum, wangi, } \\
\text { homey }\end{array}$ \\
\hline Jingga & Lezat dan hangat \\
\hline Merah & Panas, kuat, agresif \\
\hline Warna pucat & $\begin{array}{l}\text { Ringan, } \\
\text { rileks }\end{array}$ \\
\hline Merah muda & Romantis \\
\hline
\end{tabular}

Untuk proses perancangan, warna yang cocok dengan karakteristik dari Sekolah Tinggi Astronomi dan Kedirgantaraan adalah warnawarna krem atau putih dan warna pucat. Sedangkan untuk massa seperti asrama bisa mengkombinasikan warna pucat dengan kuningjingga untuk menampilkan kesan yang nyaman untuk ditinggali.

\subsection{Analisis Material}

Material yang cocok dengan karakteristik dari Sekolah Tinggi Astronomi dan Kedirgantaraan adalah material-material yang memiliki kesan formal dan tahan lama. Material yang dipilih juga harus mempertimbangkan aspek dari arsitektur berkelanjutan yang efisien, konservatif, dan tahan lama.

Tabel 4. Material dan sifatnya.

\begin{tabular}{|c|c|c|}
\hline Material & Sifat & $\begin{array}{c}\text { Kesan dan } \\
\text { Penampilan }\end{array}$ \\
\hline Beton & $\begin{array}{l}\text { Menahan gaya } \\
\text { tekan }\end{array}$ & $\begin{array}{l}\text { Formal, } \\
\text { tegas, kokoh }\end{array}$ \\
\hline Kayu & $\begin{array}{l}\text { Mudh dibentuk } \\
\text { untuk konstruksi } \\
\text { yang ringan }\end{array}$ & $\begin{array}{l}\text { Hangat, } \\
\text { natural, dan } \\
\text { mewah }\end{array}$ \\
\hline Batu bata & $\begin{array}{l}\text { Dinamis, dapat } \\
\text { berfungsi sebagai } \\
\text { dinding pendukung } \\
\text { dan dinding } \\
\text { pengisi, fleksibel } \\
\text { untuk detail } \\
\text { arsitektur }\end{array}$ & Praktis \\
\hline Semen & $\begin{array}{l}\text { Bersifat perekat } \\
\text { atau material dasar } \\
\text { beton, mudah } \\
\text { dibentuk, mudah } \\
\text { rata, cocok untuk } \\
\text { segala warna }\end{array}$ & $\begin{array}{l}\text { Dekoratif } \\
\text { dan masif }\end{array}$ \\
\hline Batu alam & $\begin{array}{l}\text { Bersifat dingin dan } \\
\text { dapat menyerap } \\
\text { air, bertekstrur } \\
\text { kasar, dapat diolah }\end{array}$ & $\begin{array}{l}\text { Berat, kuat, } \\
\text { kokoh } \\
\text { dekoratif, } \\
\text { alami, dan } \\
\text { sederhana } \\
\end{array}$ \\
\hline Batu kapur & $\begin{array}{l}\text { Mudah digabung } \\
\text { dengan bahan lain }\end{array}$ & $\begin{array}{l}\text { Sederhana, } \\
\text { ringan, } \\
\text { alami }\end{array}$ \\
\hline Marmer & $\begin{array}{l}\text { Memiliki corak } \\
\text { khas, kaku dan } \\
\text { sulit dibengkok }\end{array}$ & $\begin{array}{l}\text { Mewah, } \\
\text { kokoh, kuat, } \\
\text { dan awet }\end{array}$ \\
\hline Metal & Efisien & $\begin{array}{l}\text { Berat, } \\
\text { dingin }\end{array}$ \\
\hline Alumunium & $\begin{array}{l}\text { Efisien, kuat, } \\
\text { mudah dibentuk }\end{array}$ & $\begin{array}{l}\text { Dinamis, } \\
\text { ringan }\end{array}$ \\
\hline Plastik & Mudah dibentuk, & Dinamis, \\
\hline
\end{tabular}




\begin{tabular}{|l|l|l|}
\hline & tidak kuat & ringan \\
\hline Baja & $\begin{array}{l}\text { Hanya dapat } \\
\text { menahan gaya } \\
\text { Tarik }\end{array}$ & $\begin{array}{l}\text { Keras dan } \\
\text { kokoh }\end{array}$ \\
\hline Kaca & $\begin{array}{l}\text { Tembus cahaya } \\
\text { dan tidak } \\
\text { mempunyai sifat } \\
\text { isolasi }\end{array}$ & $\begin{array}{l}\text { Rentan dan } \\
\text { dinamis }\end{array}$ \\
\hline
\end{tabular}

Sebagai bangunan yang bersifat formal, material yang cocok untuk dikombinasikan di Sekolah Tinggi Astronomi dan Kedirgantaraan adalah beton, kayu, batu bata, semen, baja, metal, dan kaca.

\subsection{Analisis Struktur}

Struktur merupakan penopang bangunan dan menentukan bentuk bangunan. Dasar pertimbangan yang digunakan dalam menentukan penggunaan struktur adalah sebagai berikut.

1. Keadaan tanah.

2. Pengaruh struktur terhadap bentuk bangunan.

3. Ketahanan struktur.

4. Struktur memberikan optimalisasi ruang.

\subsubsection{Substruktur}

Pondasi yang digunakan adalah pondasi sumuran karena tanah pada lokasi cenderung lembab sehingga tanah keras berada jauh di bawah permukaan tanah.

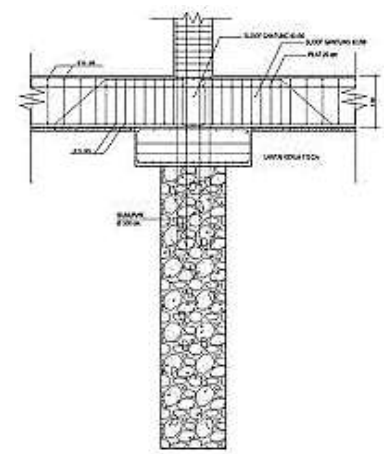

Gambar 8. Pondasi sumuran.

\subsubsection{Superstruktur}

Untuk mengutamakan efiensi ruang, superstruktur yang digunakan adalah struktur rangka batang dengan beton bertulang.

\subsubsection{Struktur atap}

Struktur atap menggunakan sistem rangka baja ringan yang menyesuaikan bentang atap.

\subsection{Analisis Arsitektur Berkelanjutan}

Arsitektur berkelanjutan diterapkan melalui tiga aspek.

\subsubsection{Efisiensi}

Dengan penerapan efisiensi lahan pada arsitektur berkelanjutan, luasan yang digunakan sebagai bangunan tidak menutupi semua lahan sehingga zona terbuka hijau banyak terdapat pada tapak.

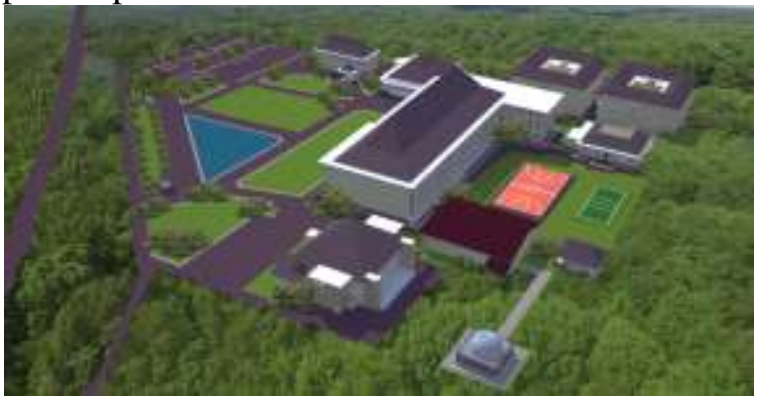

Gambar 9. Perspektif kawasan tapak.

Dari gambar perspektif kawasan terlihat hasil dari pemintakatan. Massa-massa bangunan disusun berdasarkan pola linier.

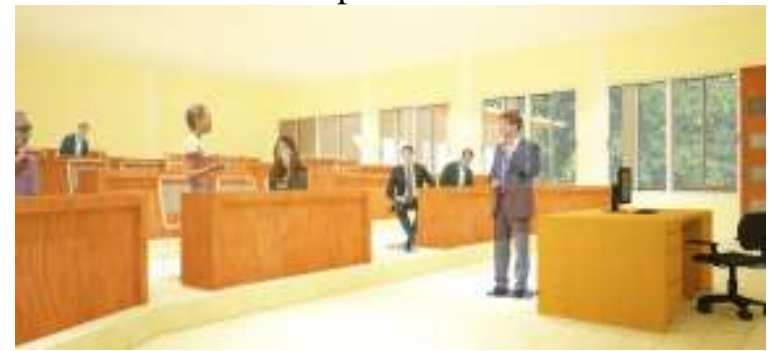

Gambar 10. Interior ruang kelas.

Bukaan pada bangunan bertujuan sebagai efisiensi penggunaan energi. Bukaan tersebut merupakan hasil dari analisis pergerakan matahari dan juga pergerakan angin.

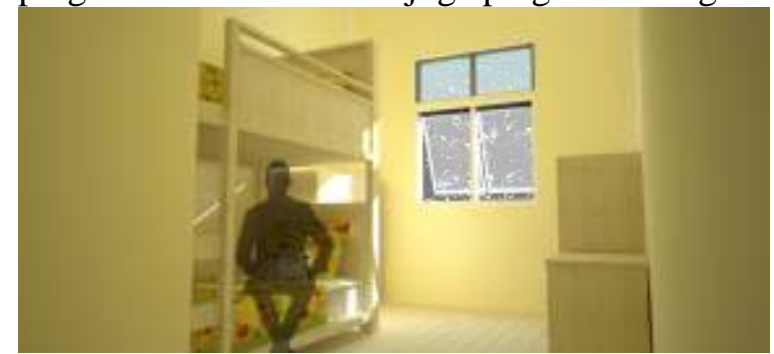

Gambar 11. Interior kamar asrama.

Bukaan memungkinkan cahaya dan penghawaan alami dapat masuk ke dalam ruangan pada bangunan. Tentu memberikan manfaat untuk menghemat penggunaan energi pada bangunan. 


\subsubsection{Konservasi}

Konservasi diaplikasikan pada material yang dapat diperbaharui, yaitu pemanfaatan kayu jati dan batu alam sebagai material bangunan.

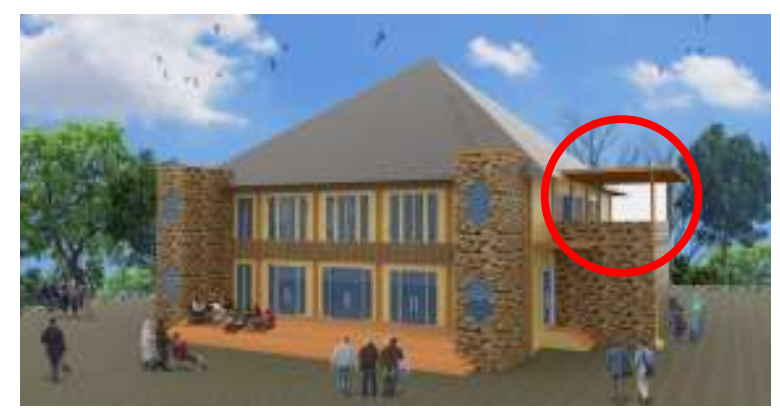

Gambar 12. Bangunan masjid.

Di Gunungkidul juga banyak terdapat hutan jati. Penggunaan jati juga mengaplikasikan tebang pilih untuk menjaga keberlanjutan lingkungan.

\subsubsection{Durabilitas}

Durabilitas diaplikasikan pada pemilihan tapak. Pemilihan lokasi di Gunungkidul merupakan hasil dari pertimbangan ketahanan bangunan. Kabupaten Gunungkidul jauh dari Gunung Merapi dan masih memiliki kondisi ekologi yang hijau. Lokasi Gunung Merapi dihindari karena terdapat bagian langit yang tertutup gunung saat observasi dan status Gunung Merapi masih menjadi gunung api aktif. Durabilitas juga diaplikasikan pada analisis perencanaan ruangan yang didasarkkan pada preseden dan kurikulum, sehingga menghasilkan ruangan yang sesuai fungsi kegiatan.

\section{KESIMPULAN (KONSEP DESAIN)}

Sekolah Tinggi Astronomi dan Kedirgantaraaan dengan Penerapan Arsitektur Berkelanjutan di Yogyakarta, adalah sebuah lembaga pendidikan pada jenjang perguruan tinggi, yang khusus mempelajari ilmu astronomi dan kedirgantaraan. Sistem yang diterapkan di kampus adalah pembelajaran semi-militer. Pengolahan dan penataan peruangan dapat dilihat pada Lampiran 1.

Nama : Sekolah Tinggi Astronomi

Lokasi : Desa Gading, Kecamatan Playen, Kabupaten Gunungkidul
Luas lahan $\quad: \pm 30.000 \mathrm{~m}^{2}$

Luas bangunan : $\pm 10.742 \mathrm{~m}^{2}$ dengan rincian

- Zona Pengelola $\pm 403,53 \mathrm{~m}^{2}$

- Zona Pendidikan $\pm 4892,46 \mathrm{~m}^{2}$

- Zona Pendukung dan

Penunjang $\pm 3655,6 \mathrm{~m}^{2}$

- Flow $20 \% \pm 1790,3 \mathrm{~m}^{2}$

Jurusan \& daya tampung

- S1 Astronomi (34org/thn)

- S1 Teknik Kedirgantaraan (40 org/thn)

- D3 Aeronautika (36 org/thn)

Berdasarkan analisis yang telah dilakukan, aplikasi analisis ke dalam arsitektur berkelanjutan adalah sebagai berikut.

1. Efisiensi

Diterapkan melalui

a. Penggunaan luasan bangunan yang tidak menutupi semua lahan sehingga masih tersedia banyak lahan terbuka hijau sebagai resapan.

b. Apikasi bukaan sebagai hasil dari analisis pergerakan matahari dan angin untuk menghasilkan pencahayaan dan penghawaan alami yang dapat menghemat energi pada bangunan.

2. Konservasi

Diaplikasikan pada penggunaan material bangunan, antara lain penggunaan kayu jati dan batu alam.

3. Durabilitas

Diaplikasikan pada pemilihan tapak bangunan. Pemilihan tapak yang menghindari Gunung Merapi sebagai bentuk meminimalisasi tapak dari bencana.

Selain hasil dari metode, berikut merupakan kesimpulan dari analisis lain yang sudah dilakukan.

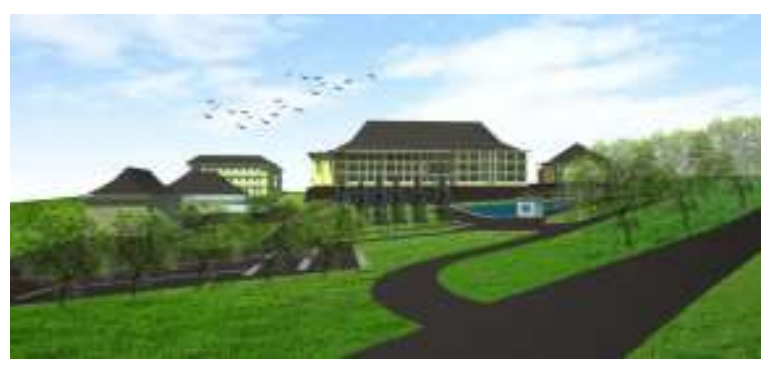

Gambar 13. Jalur ME tapak.

Main entrance pada tapak dirancang untuk mempermudah pencapaian dari jalan utama. 


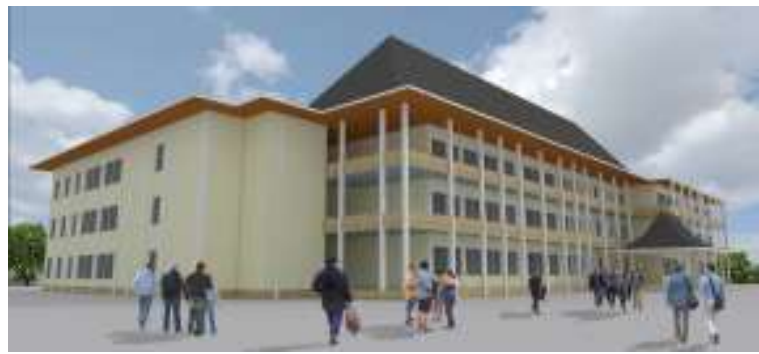

Gambar 14. Gedung kuliah.

Tampilan bangunan menyesuaikan keadaan lingkungan yang masih menggunakan rumah tradisional Jawa dengan atap joglo, limasan, dan pelana.

\section{REFERENSI}

Gill, Martha. 2000. Color Harmony Pastels: A Guidebook for Creating Great Color Combinations. Beverly: Rockport Publishers.

Hendraningsih. 1985. Peran, Kesan dan Pesan Bentuk-bentuk Arsitektur. Sleman: Djambatan.

Neuman, David J. dan Kliment, Stephen A.. 2003. Building Type Basics for College and University Facilities. New York: John Wiley \& Sons, Inc.

Steele, James. 1997. Sustainable Architecture: Principles, Paradigms, and Case Studies. New York: McGraw-Hill. 
Lampiran 1. Siteplan.

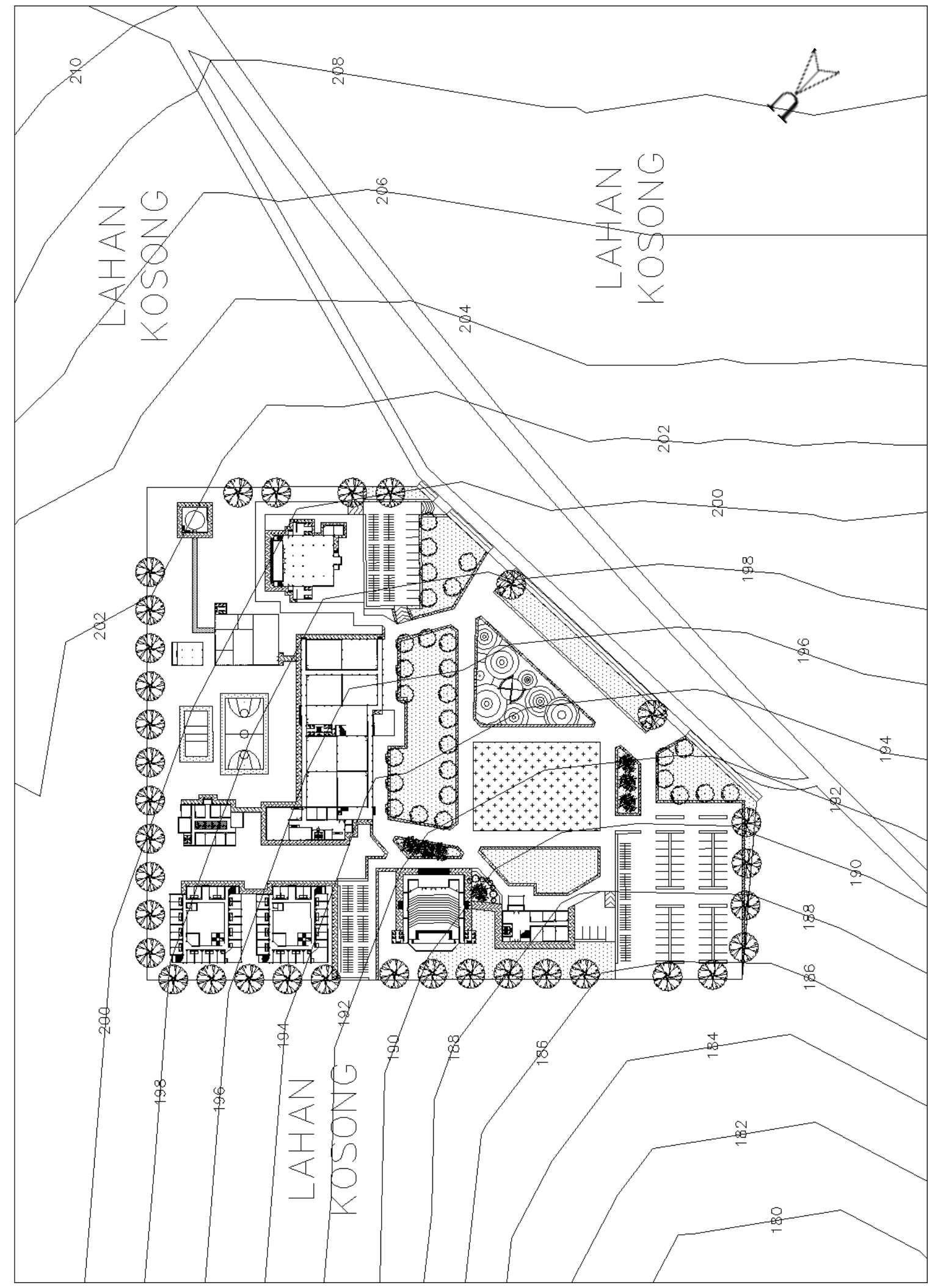

